\title{
Development and distribution of the non-indigenous Pacific oyster (Crassostrea gigas) in the Dutch Wadden Sea
}

\author{
Frouke Fey $\cdot$ Norbert Dankers $\cdot$ Josien Steenbergen $\cdot$ Kees Goudswaard
}

Received: 17 April 2008/Accepted: 10 December 2008/Published online: 1 July 2009

(C) The Author(s) 2009. This article is published with open access at Springerlink.com

\begin{abstract}
Pacific oysters (Crassostrea gigas) were first observed in the Dutch Wadden Sea near Texel in 1983. The population increased slowly in the beginning but grew exponentially from the mid-1990s onwards, although now some stabilisation seems to be occurring. They occur on a variety of substrates such as mussel beds (Mytilus edulis), shell banks, dikes and poles. After initial settlement spat may fall on older individuals and congregate to dense clumps and subsequently form reefs. Individual Pacific oysters grow 3-4 cm long in their first year and 2-3 cm in their second year. Many mussel beds (Mytilus edulis) are slowly taken over by Pacific oysters, but there are also several reports of mussel spat settling on Pacific oyster reefs. This might in the end result in combined reefs. Successful Pacific oyster spat fall seems to be related to high summer temperatures, but also after mild summers much spat can be found on old (Pacific oyster) shells. Predation is of limited importance. Mortality factors are unknown, but every now and then unexplained mass mortality occurs. The gradual spread of the Pacific oyster in the Dutch Wadden Sea is documented in the first instance based on historical and anecdotal information. At the start of the more in-depth investigation in 2002, Pacific oysters of all size classes were already present near Texel. Near Ameland the development could be followed from the first observed settlement. On dense reefs each square metre may contain more than 500 adult Pacific oysters, weighing more than $100 \mathrm{~kg}$ per $\mathrm{m}^{2}$ fresh weight.
\end{abstract}

Keywords Pacific oyster - Crassostrea gigas · Mussel bed · Wadden Sea · Invasive species

\section{Introduction}

The Wadden Sea is a large intertidal ecosystem along the Eastern shore of the North Sea and extends from the north of The Netherlands to Denmark. It is the largest wetland area of Europe and contains the largest unbroken stretch of intertidal flats worldwide. In ecological terms, the Wadden Sea benthos is dominated by filter feeders (Baird et al. 2004), and in

F. Fey $(\varangle) \cdot$ N. Dankers · J. Steenbergen · K. Goudswaard

IMARES, part of Wageningen UR, P.O. Box 167, 1790AD Den Burg, Texel, The Netherlands

e-mail: frouke.fey@wur.nl 
historic time oyster beds (Ostrea edulis) and Sabellaria reefs (Sabellaria spinulosa) were regarded as characteristic features of the tidal channels in the Wadden Sea (Hagmeier and Kändler 1927). Until the beginning of the twentieth century the native European oyster (Ostrea edulis) was widely spread in the Wadden Sea, but declined due to overfishing (Reise 1982). The last living bed of European oyster in the international Wadden Sea was found in 1940 (Hagmeier 1941).

The spread of the non-indigenous Pacific oyster (Crassostrea gigas) over The Netherlands started with its introduction for cultivation purposes in the Dutch Oosterschelde in 1964 (Drinkwaard 1999). The Pacific oyster occurs naturally in marine waters of Japan and southeast Asia. Although it was thought that the low water temperatures would prevent natural production in the Oosterschelde, between 1974 and 1976 the first massive spat fall took place. An exponential increase of wild populations occurred in later years, and from there it was spread all over the Dutch coastal waters (Dankers et al. 2006). Since the beginning of the 1980s wild Pacific oysters have been reported from the Dutch Wadden Sea, starting from Texel (Bruins 1983), where they were introduced (Tydeman 2008).

In 1996 a first settlement occurred in the Niedersachsen part of the German Wadden Sea area, which may have dispersed from The Netherlands by natural means (Wehrmann et al. 2000; Nehring 2003). In 1986 Pacific oysters were introduced in the Northern Wadden Sea at Sylt for cultivation (Reise 1998), and in 1991 the first oysters were found outside culture plots in the Northern Wadden Sea.

At the start of the new millennium it became clear that the Pacific oyster occurred throughout the Dutch Wadden Sea, and since 2004 Pacific oysters have occurred to such an extent that yearly increases in standing stock can be roughly quantified on the basis of standard shellfish surveys [cockle (Cerastoderma edule) and mussel (Mytilus edulis)].

We will give an overview of the development of the Pacific oyster in the Dutch Wadden Sea from the early 1980 s to the current situation. For this we will combine data of shellfish surveys with data on expansion of individual oyster reefs and yearly growth of individual oysters of the subtidal and intertidal areas of the Dutch Wadden Sea.

\section{Method}

Occurrence and distribution of Pacific oysters in the Dutch Wadden Sea

Until now no survey program exists that focuses on the development of the Pacific oyster (Crassostrea gigas) in the Dutch Wadden Sea. The invasion of the Pacific oyster between 1983 and 2003 is reconstructed from reports of private persons in these years and from forms that were distributed by Internet (www.Waddenzee.nl) in 2002 and 2003. Respondents were asked to give information on the location, density, size, substrate and year of first record.

Since 1990, every year in spring (March, April and May), the Wadden Sea has been sampled for the distribution of cockles (Cerastoderma edule) and mussels (Mytilus edulis). Sampling is done either with an adapted mechanical cockle dredge $\left(0.4 \mathrm{~m}^{2}, 7 \mathrm{~cm}\right.$ depth $)$ or a hand-held sampling device $\left(0.1 \mathrm{~m}^{2}, 7 \mathrm{~cm}\right.$ depth). Samples are sieved with a $5 \times 5$-mm sieve. All data from these samples are calculated to individuals $/ \mathrm{m}^{2}$ and total fresh weight $/ \mathrm{m}^{2}$ (Goudswaard et al. 2007). Between 1,370 and 1,775 samples were taken each year, following a stratified approach based on occurrence of cockle (Cerastoderma edule) or mussel (Mytilus edulis) beds, not on Pacific oyster occurrence. The position of the 
samples (1,110-4,440 $\mathrm{m}$ apart) was based on data of previous surveys and information from fishermen on the occurrence of cockle or mussel beds.

Intertidal mussel beds are also charted with GPS, and occurrence of Pacific oysters has been documented briefly in recent years.

\section{Development of individual Pacific oyster reefs}

Pacific oyster (Crassostrea gigas) development on three locations has been followed since 2002 by establishing the contours of the Pacific oyster reefs (congregated oysters in large densities) and by measuring Pacific oyster lengths (in $\mathrm{cm}$ ) in samples of $0.5 \times 0.5 \mathrm{~m}^{2}$.

On a Pacific oyster reef near Texel (location 216) every year three squares at fixed locations are analysed. On a mussel bed (Mytilus edulis) near Ameland (location 502) every year four squares at fixed locations are analysed. On this mussel bed Pacific oysters also occurred in the regular samples taken during mussel surveys. These consisted of five yearly samples of $0.05 \mathrm{~m}^{2}$. On the dyke near Oudeschild (Texel) two sample transects (O-10 and O-13) of approximately $6 \mathrm{~m}$ length and $0.5 \mathrm{~m}$ width were established from high water level to low water level.

The contours of the Pacific oyster reefs are established by satellite positioning (GPS) of the borders of the reef. Only parts that have a cover of more than 5\% (Brinkman et al. 2003) are considered part of the reef. Inlets that are bigger than $25 \mathrm{~m}$ are recognised, and lumps of Pacific oysters laying $25 \mathrm{~m}$ apart from the reef are treated as separate (patch) reefs. The contours of the reefs are analysed with GIS.

\section{Results}

Current status of the Pacific oyster in the Dutch Wadden Sea

From data on first occurrences of Pacific oysters (Crassostrea gigas) in the Dutch Wadden Sea, it is clear that a relatively long period elapsed between the first record (1983) and reports on further spread in the area around 1995 (Fig. 1). Only just before the start of the new millennium did it become clear that the Pacific oyster had spread throughout the entire Dutch part of the Wadden Sea.

In the early stages of Pacific oyster development only small areas were covered with Pacific oysters. Information on the substrates where Pacific oysters were found and corresponding abundances came from respondents to the Internet inquiry (Fig. 2). Since 2004, however, the Pacific oyster abundance increased in such a way that it could be estimated through yearly shellfish surveys (Table 1). This survey is based on the occurrence of mussels (Mytilus edulis) and cockles (Cerastoderma edule) and not on the stratification of Pacific oysters. Therefore, the reliability of estimating the standing stock of the Pacific oyster is still far from optimal. Nevertheless, these estimates can be used to assess the increase in Pacific oyster occurrences (Table 1; Fig. 3).

Before 2002 Pacific oysters were found in fewer than 4 out of more than 1,500 samples. After 2005 this increased to more than 70. The mean biomass of Pacific oysters within these samples increased from 132 to $2,050 \mathrm{~g} / \mathrm{m}^{2}$ fresh weight (Fig. 3). From these results it can be concluded that the Pacific oyster increased explosively between 2003 and 2005, but it seems to have stabilised since then. A comparably fast increase has also been found in the German Wadden Sea (Diederich et al. 2005; Brandt et al. 2008; Schmidt et al. 2008). 


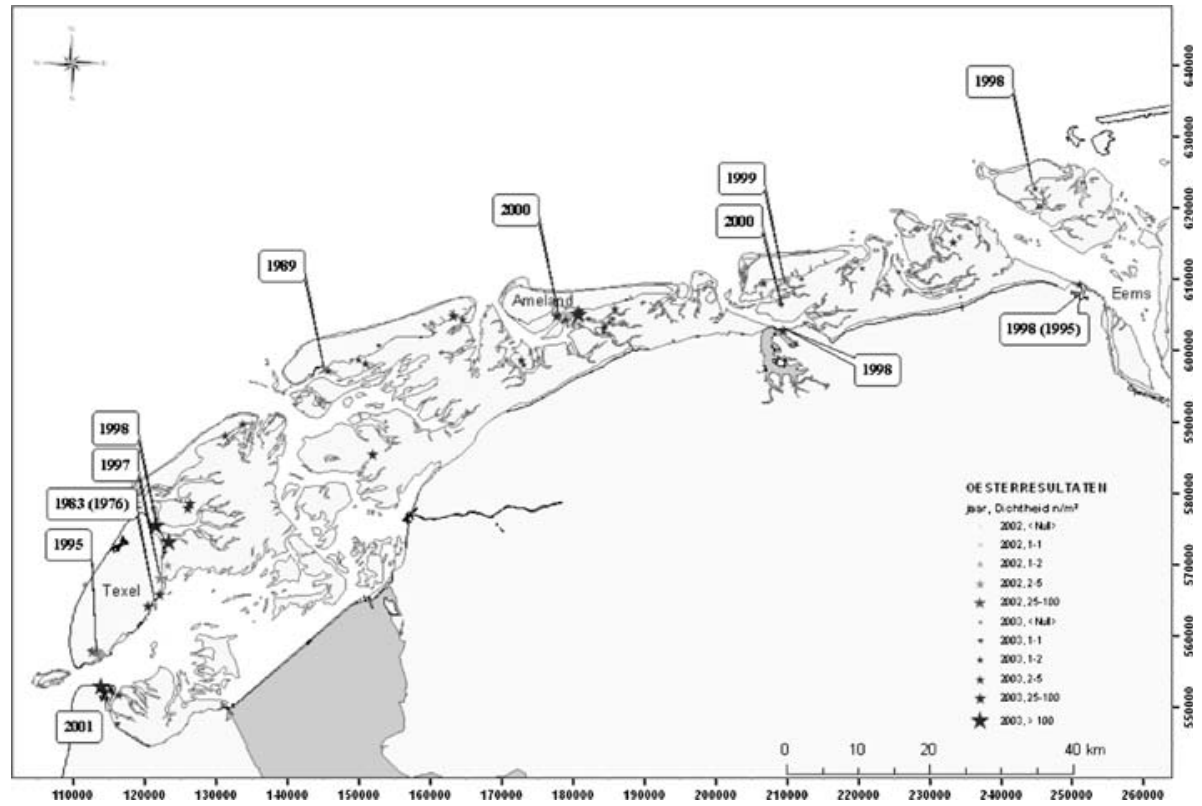

Fig. 1 Reports by private persons on the Interwad website (www.waddenzee.nl) in 2002 and 2003 of Pacific oyster (Crassostrea gigas) occurrences in the Dutch Wadden Sea. Years indicate first reports at specified locations, years between brackets indicate the supposed year of settlement based on the size of the oyster. Coordinate system in Dutch national reference system RD

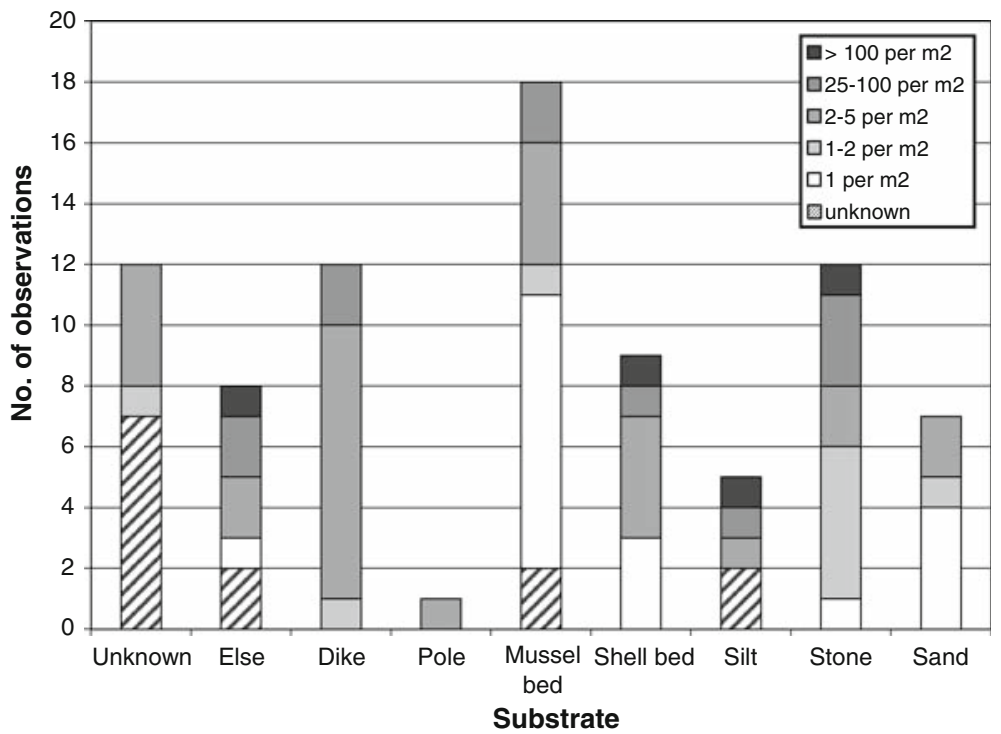

Fig. 2 Substrate for settling of Pacific oysters (Crassostrea gigas) in the Dutch Wadden Sea. Based on Internet enquiry in 2002 and 2003 
Table 1 Samples containing Pacific oysters (Crassostrea gigas) in yearly shellfish surveys (spring) based on mussel (Mytilus edulis) and cockle (Cerastoderma edule) occurrences

\begin{tabular}{lll}
\hline Year & Total sampling points & Sampling points with oysters \\
\hline 2001 & 1,617 & 1 \\
2002 & 1,663 & 4 \\
2003 & 1,554 & 4 \\
2004 & 1,775 & 43 \\
2005 & 1,370 & 88 \\
2006 & 1,415 & 70 \\
\hline
\end{tabular}

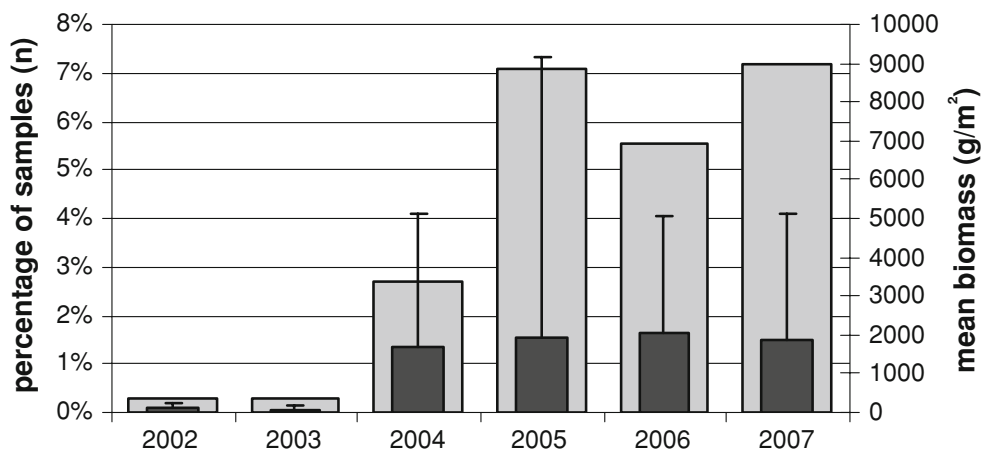

$\square$ percentage of samples with oysters $\square$ mean biomass $\left(\mathrm{g} / \mathrm{m}^{2}\right)$ in samples

Fig. 3 Percentage of samples (grey bars) in the yearly tidal shellfish survey (1,293 samples), based on mussel (Mytilus edulis) and cockle (Cerastoderma edule) occurrences, in which Pacific oyster (Crassostrea gigas) was found and the mean biomass (fresh weight? $\mathrm{g} / \mathrm{m}^{2}$ ) of oysters in these samples (black bars) with standard deviation

Development of individual Pacific oyster reefs

Since 2002 several locations with Pacific oyster development have been followed on a yearly basis. The measurements focus mainly on the length-frequency distribution of Pacific oysters and on the contours of the Pacific oyster reefs.

Pacific oysters at location 216 near Texel (Fig. 4) settled on a dead shell bank/bed (mainly dead Cerastoderma edule) in 1999. In 2002 the Pacific oysters started to take a vertical position, new spat fell onto older individuals (2002 and 2003), and they congregated to large cemented clumps, thus forming a reef. In 2006 this reef was 17.4 ha (Fig. 4) with a mean abundance of 317 oysters $/ \mathrm{m}^{2}$ on the Pacific oyster-covered parts (Fig. 5a, b). The area of the reef does not seem to have increased much since 2004 (Fig. 4). The reef consists of many different size classes (Fig. 6b).

Several small trenches and pools occur in the reef, which contain, among others, gobies (Gobio gobio) and shrimp (Crangon crangon). Eider ducks (Somateria mollissima), red knots (Calidris canutus), Eurasian spoonbills (Platalea leucorodia) and little egrets (Egretta garzetta) have been observed at this oyster reef and its interspaces (own observations). On the Pacific oyster reef Gutweed (Enteromorpha sp.), sea letuce (Ulva spec.) and the red algae Gracilaria verrucosa occur. On the shells the periwinkle Littorina littorea is very common.

Near Ameland (location 502, Fig. 6) Pacific oysters have settled on a mussel bed (Mytilus edulis). Part of this mussel bed, which originates from 1994, is already 


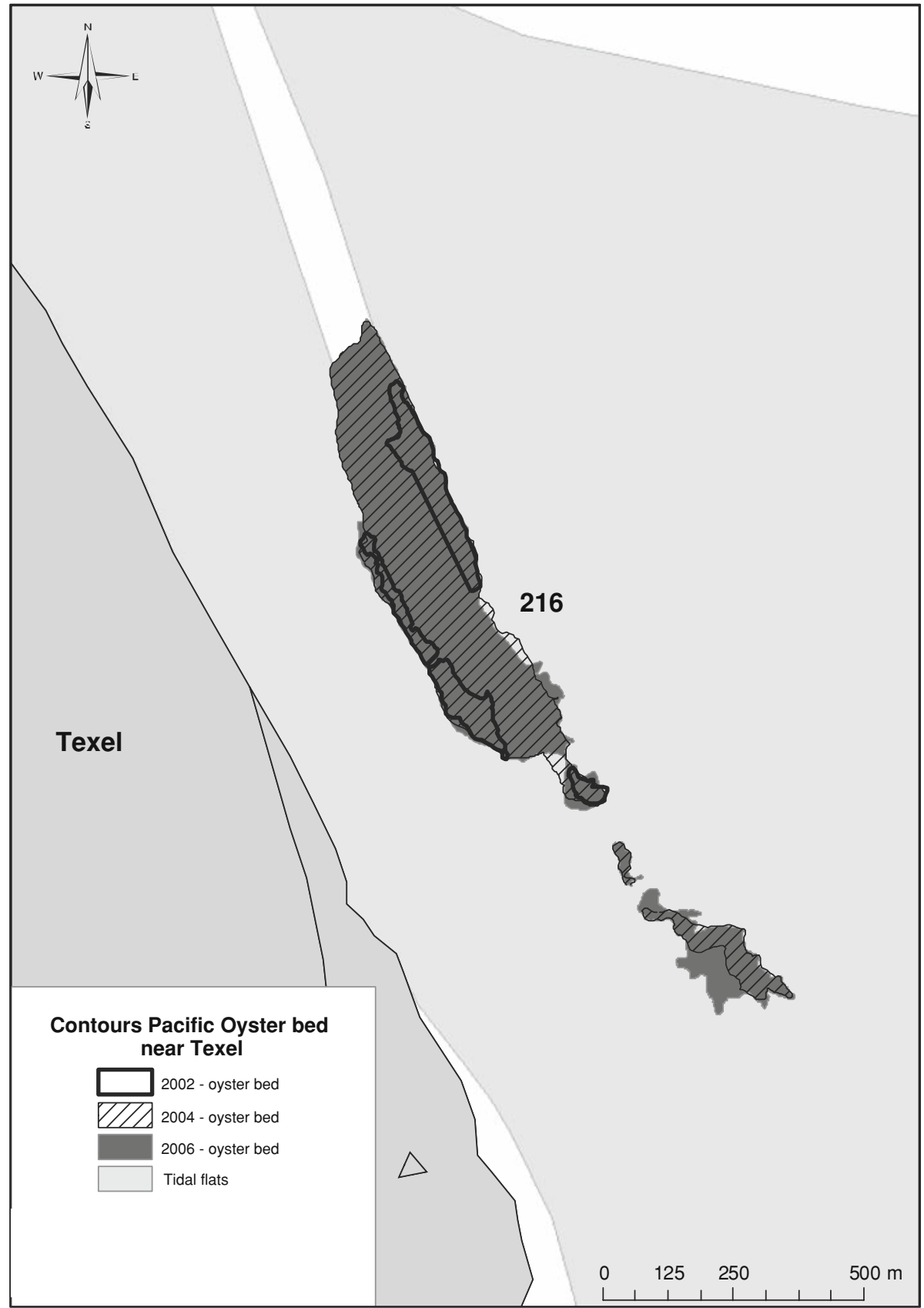

Fig. 4 Development of the contours of the Pacific oyster (Crassostrea gigas) reef (216) near Texel from 2002 to 2006

transformed into a Pacific oyster reef. In 2000 the first Pacific oyster was found on this mussel bed. Since 2002 the size classes of these Pacific oysters have been measured, and the progress of replacement of mussels (Mytilus edulis) by Pacific oysters has been 

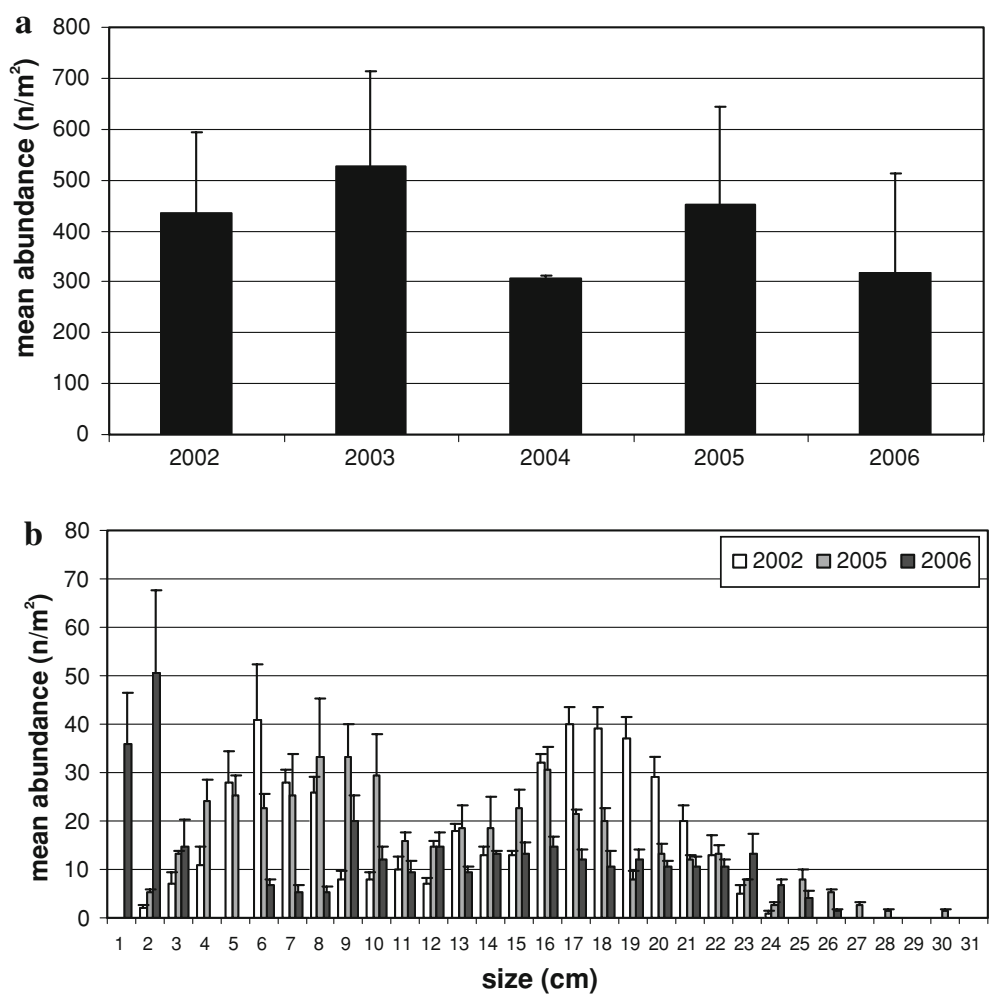

Fig. 5 a Mean abundance of Pacific oysters (Crassostrea gigas) per $\mathrm{m}^{2}$ on the oyster reef near Texel (Zeeburg, 216). b Mean abundance per length class (in $\mathrm{cm}$ ) on the Pacific oyster (Crassostrea gigas) reef near Texel (Zeeburg, 216)

monitored. Pacific oysters are now mainly concentrated on the eastern side of the mussel bed and cover an area of about 26.5 ha (Fig. 6) with a mean abundance of 336 Pacific oysters $/ \mathrm{m}^{2}$ on the patches (Fig. 7a, b). On the mussel bed both Gracilaria and Fucus sp. occur. The abundance and length frequency distribution data (Fig. 7a, b) show a notable increase in both number and size of Pacific oysters on this location. In the five samples of $0.05 \mathrm{~m}^{2}$ taken for the mussel inventories, Pacific oysters were observed from 2003 onwards (Table 2). Variation between samples is such that they are unreliable for biomass estimates for the bed as a whole.

Near Oudeschild (Texel location O-10 and O-13) Pacific oysters have settled on the stones of the dike. First settlement probably took place around 1999 (Figs. 8, 9). It is clear that abundances are higher on the lower parts of the dike (Fig. 10). In 2003 a notable increase in abundance took place, which is a clear result of the spat fall in 2002 (Fig. 8). The spat fall of 2003, which was clearly visible at several locations in the tidal flats in the Wadden Sea, did not result in an increase in oyster densities on the dike in 2004. On one of the transects (O-10) a notable decrease in oyster densities occurred in 2004. The oyster abundance on the two transects of the dike of Oudeschild $\left(\mathrm{O}-10=43\right.$ inds. $/ \mathrm{m}^{2}$ and $\mathrm{O}-13=38$ inds. $\left./ \mathrm{m}^{2}\right)$ (Figs. 10,11$)$ seems to be considerably lower than the density on the tidal flats (Zeeburg-216 $=317$ inds. $/ \mathrm{m}^{2}$ and Ameland$502=336$ inds. $\left./ \mathrm{m}^{2}\right)$. 


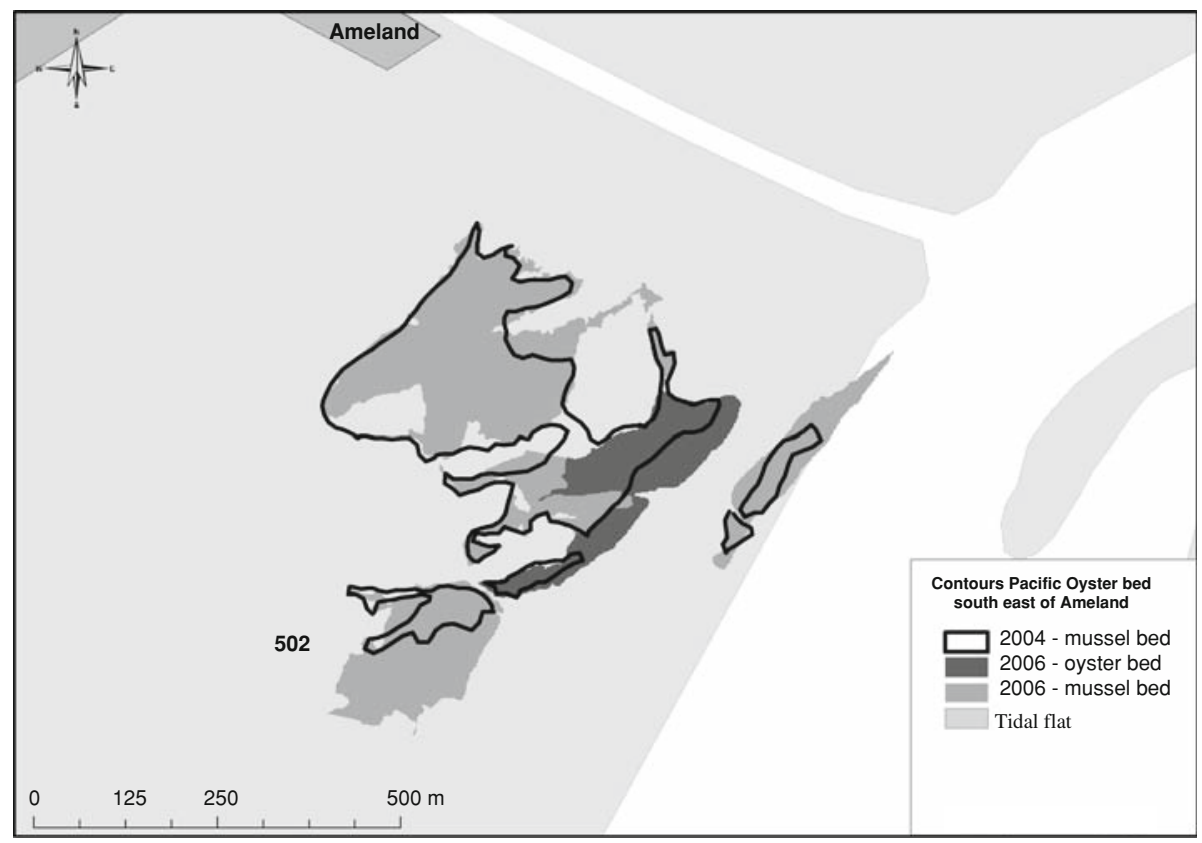

Fig. 6 Mussel (Mytilus edulis) bed (502) near Ameland, which has been partly transformed into a Pacific oyster (Crassostrea gigas) reef

Based on abundances and size classes and an equation developed by Büttger and Nehls (personnel communication), the Pacific oyster biomass was calculated for the samples from beds 216 and 502 (Fig. 11). In the period that the oyster biomass (fresh weight) was increasing in Ameland, it stabilised or even decreased at Zeeburg. Still, the total Pacific oyster biomass (fresh weight) at Zeeburg was considerably higher.

Reproduction and individual growth of Pacific oysters

Although no data are available on the quantity of Pacific oyster recruitment in the Dutch Wadden Sea, from the length-frequency distribution data on these different locations it can be deduced that successful spat fall did occur every year between 2002 and 2006.

Although no study has been performed aiming specifically at Pacific oyster growth under special conditions and at different locations in the Wadden Sea, from several studies on length frequencies at least some information on growth can be deduced. Oysters seem to grow up to $4 \mathrm{~cm}$ in the first year (this study; Cadée 2000; Reise 1998; Wehrmann et al. 2000; Schmidt et al. 2008). Cadée (2000) also measured growth of second year oysters in the Mokbaai (Texel). He found an increase from 3 to $8 \mathrm{~cm}$ between April and August.

In combination with the data on size distribution presented in this article, it can be deduced that oysters grow about $3-4 \mathrm{~cm}$ in the first year and about $2-3 \mathrm{~cm}$ in the second year (Figs. 6, 9, and 11). 

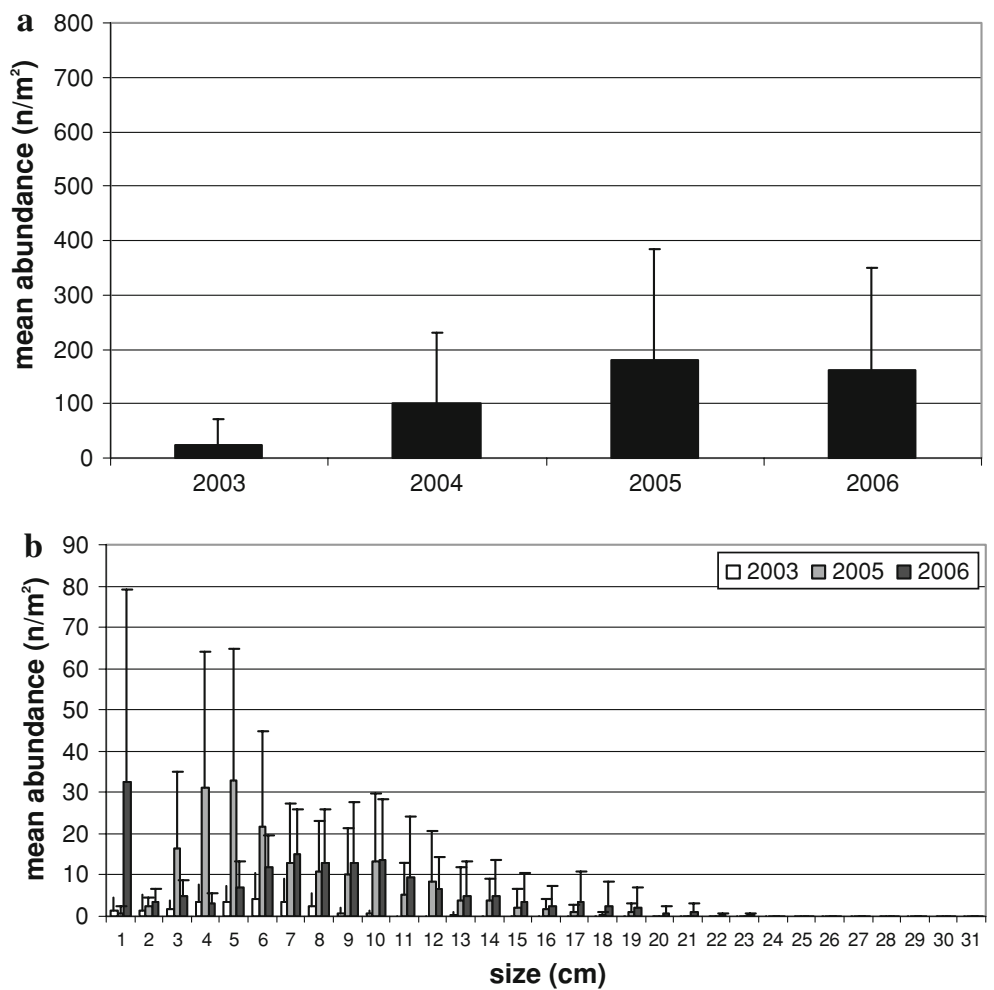

Fig. 7 a Mean abundance of Pacific oysters (Crassostrea gigas) per $\mathrm{m}^{2}$ on a mussel (Mytilus edulis) bed (502) near Ameland. b Mean abundance per length class (in $\mathrm{cm}$ ) of Pacific oysters (Crassostrea gigas) on a mussel (Mytilus edulis) bed (502) near Ameland

Table 2 Abundance of Pacific oysters (Crassostrea gigas) in samples from mussel (Mytilus edulis) beds

\begin{tabular}{llllllllll}
\hline Year & $\begin{array}{l}\text { Samples } \\
\text { with } \\
\text { oysters }\end{array}$ & $\begin{array}{l}\text { Abundance } \\
(n) \text { in } \\
\text { sample } 1\end{array}$ & $\begin{array}{l}\text { Abundance } \\
(n) \text { in } \\
\text { sample } 2\end{array}$ & $\begin{array}{l}\text { Abundance } \\
(n) \text { in } \\
\text { sample } 3\end{array}$ & $\begin{array}{l}\text { Abundance } \\
(n) \text { in } \\
\text { sample } 4\end{array}$ & $\begin{array}{l}\text { Weigt } \\
(\mathrm{g}) \text { in } \\
\text { sample } \\
1\end{array}$ & $\begin{array}{l}\text { Weigt } \\
(\mathrm{g}) \text { in } \\
\text { sample } \\
2\end{array}$ & $\begin{array}{l}\text { Weigt } \\
(\mathrm{g}) \text { in } \\
\text { sample } \\
3\end{array}$ & $\begin{array}{l}\text { Weigt } \\
(\mathrm{g}) \text { in } \\
\text { sample } \\
4\end{array}$ \\
\hline 2003 & 1 & 5 & & & & 162 & & \\
2004 & 3 & 15 & 13 & 1 & & 284 & 570 & 10 \\
2005 & 2 & 45 & 25 & & & 1,725 & 536 & \\
2006 & 2 & 10 & 10 & & & 494 & 292 & \\
2007 & 4 & 15 & 7 & 4 & 2 & 759 & $?$ & 40 \\
\hline
\end{tabular}

Each year five samples from each bed were taken. The table gives the number of oysters in the samples and the corresponding fresh weight

Takeover of mussel beds?

Mussel bed area (Mytilus edulis) in the tidal area has increased from almost zero in the early 1990s to around 2,000 ha in 2006. Figure 12 indicates the area of Pacific oyster reefs and mussel beds with oysters in the period from 2003 to 2006. Although considerable parts 

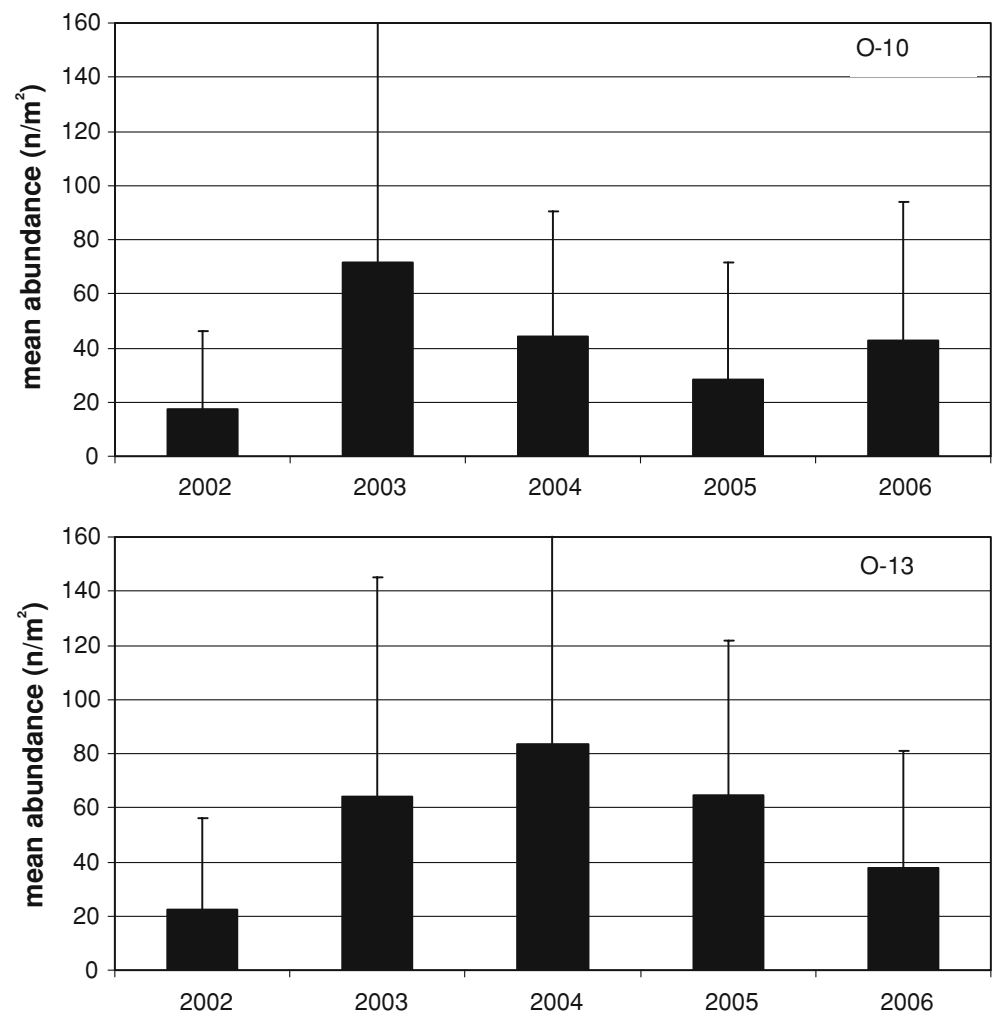

Fig. 8 Abundance of Pacific oysters (Crassostrea gigas) per $\mathrm{m}^{2}$ on the dike of Texel (location O-10 and O-13)

of mussel beds have been invaded, there is still a majority of mussel beds in the Dutch Wadden Sea with no or insignificant amounts of oysters.

\section{Discussion}

Since the new millennium the Pacific oyster seems to have established a solid place in the Wadden Sea ecosystem. Pacific oysters occur on hard substrate (dikes and stones), on other secondary hardsubstrates [e.g., mussel beds (Mytilus edulis)] and on shell banks. They can occur as clusters, patches or reefs.

Although recruitment was irregular at first (Dankers et al. 2004; Reise 1998; Wehrmann et al. 2000), wild populations have increased at a dramatic pace since around the year 2000 . Several factors might be of importance for this pattern of slow settlement followed by explosive growth. It always was expected that Pacific oysters would be at the edge of their physiological range in the Wadden Sea and would rely on high late summer temperatures, which may occur at least every 5 years (Diederich et al. 2005). However, there are indications that eco-physiological changes might have occurred, which made it possible for the Pacific oyster to reproduce in an unfavourable environment (Cardoso 2004; Wehrmann et al. 2006). In addition, the rise in temperature during the last decade, improving 

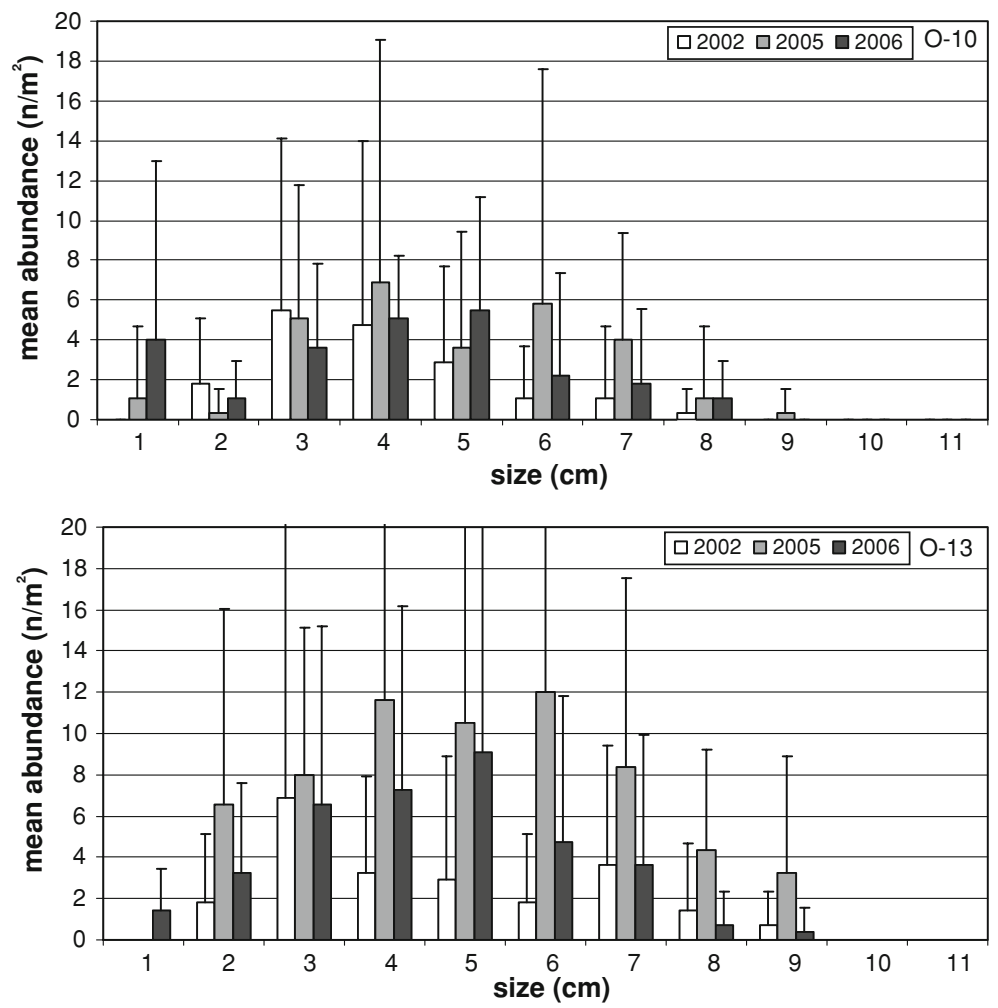

Fig. 9 Size distribution (in $\mathrm{cm}$ ) of Pacific oysters (Crassostrea gigas) on the dike of Texel (location O-10 and O-13)

environmental conditions for natural recruitment and dispersal, might explain the recent explosive growth (Diederich et al. 2005; Nehls et al. 2006; Wehrmann et al. 2006). A positive feedback mechanism might also contribute to the pattern. A study by Diederich (2005) and Wehrmann et al. (2006) has revealed that settlement of Pacific oysters is higher on conspecifics than on any other substrate. This might lead to rapid reef formation after first settlement and thus explosive growth after slow establishment.

The absence of predators might enforce a rapid expansion in a new habitat once it has been established (Colautti et al. 2004). In the Dutch Wadden Sea, Pacific oysters do not suffer from high predation levels. Crabs (Carcinus maenas) are able to open oysters of 1-3.5 cm, but prefer mussels (Mascaro and Seed 2000). Herring gulls (Larus argentatus) and oystercatchers (Haematopus ostralegus) are able to predate on Pacific oysters between 3 and $10 \mathrm{~cm}$ (Cadée 2001, 2008a, b, Wehrmann, personnel communication). In the Oosterschelde Pacific oysters suffer from suffocation by the colonial tunicate Didemnum lahillei. This species was found for the first time in the Oosterschelde in 1991, and occurrences peaked between 1996 and 1998 (de Kluijver and Dubbeldam 2003). This species does not (yet) occur in the Wadden Sea.

The highest "predation pressure" comes from humans, collecting Pacific oysters for consumption. Pacific oysters are only collected by hand in the Dutch Wadden Sea, and only smaller specimens lying individually are collected. Pacific oysters from reefs are not 

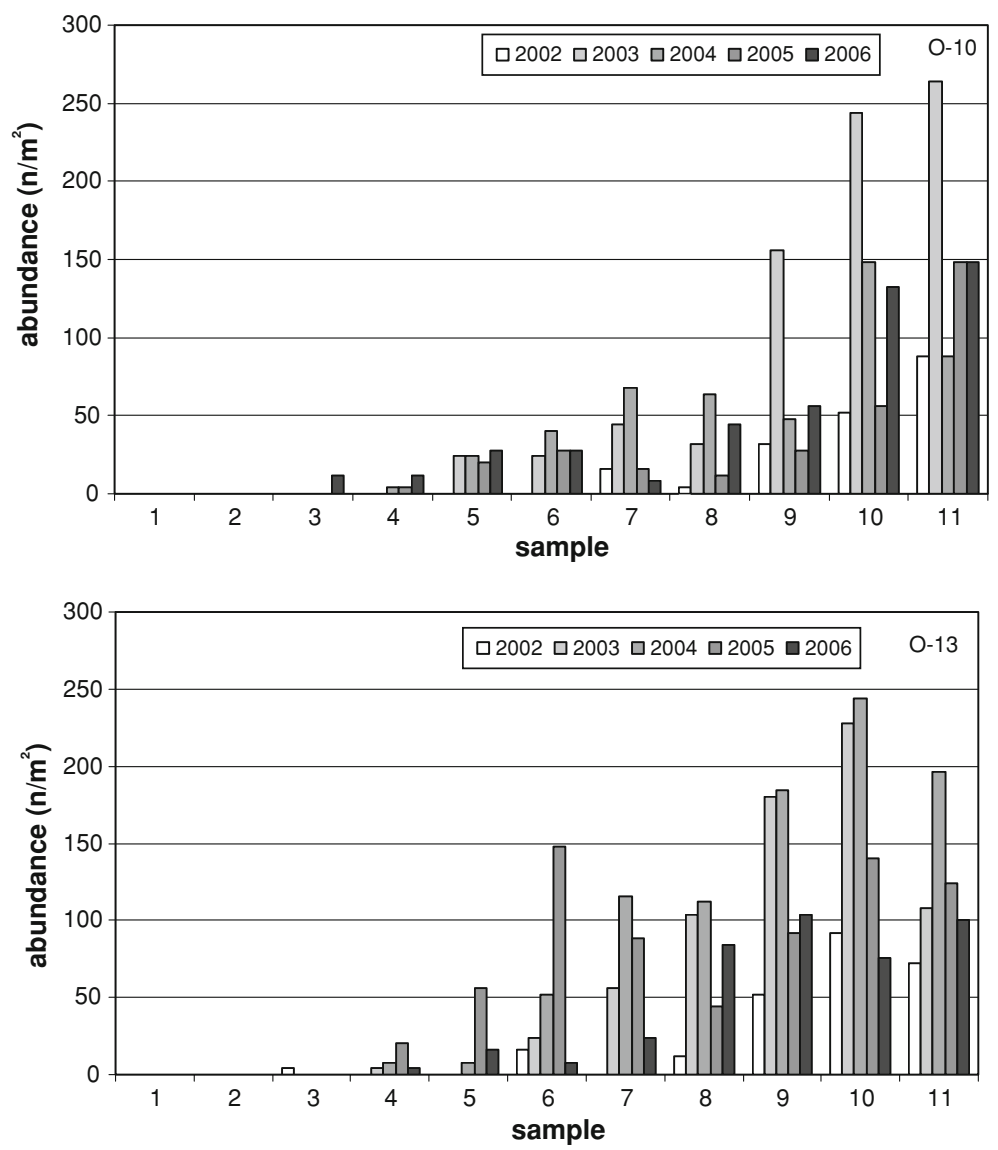

Fig. 10 Abundance of Pacific oysters (Crassostrea gigas) on the dike of Texel (location O-10 and O-13) with 11 samples from high water level to low water level
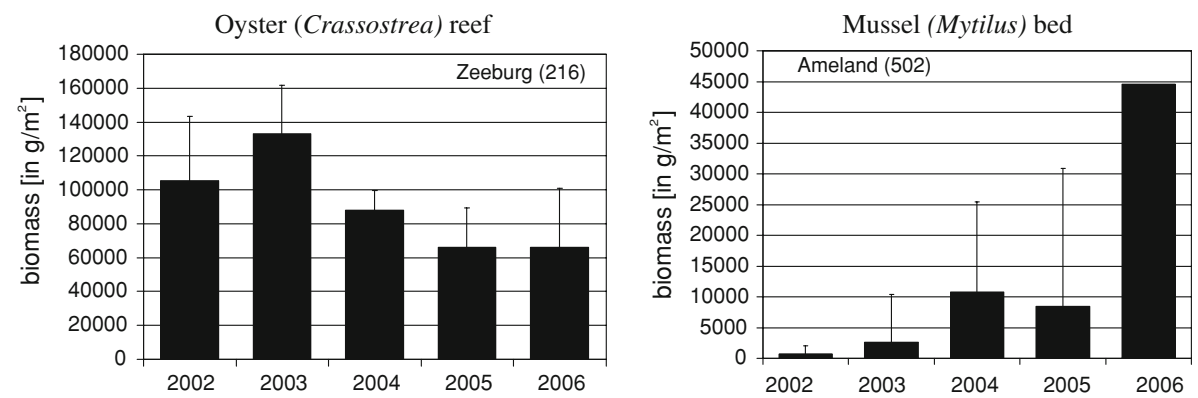

Fig. 11 Biomass (g/m² fresh weight) of Pacific oysters (Crassostrea gigas) on an oyster reef (216) (left) and mussel (Mytilus edulis) bed (502) taken over by oysters (right). Notice different scales

suitable for collection as they form inseparable clusters of individuals in different sizes and shapes. Until now no pests or diseases have been observed on Pacific oysters in the Wadden Sea (Cadée 2004). 


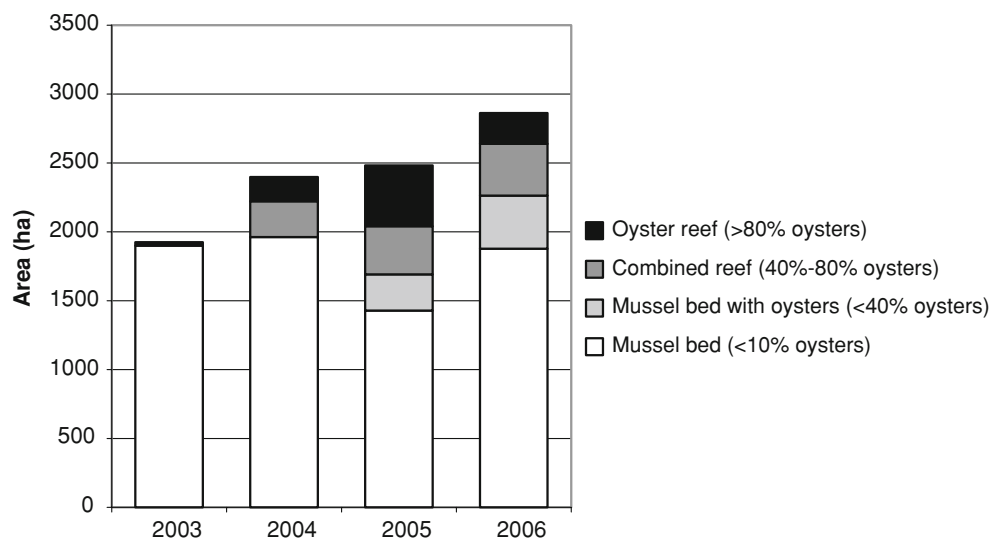

Fig. 12 Area of tidal mussel (Mytilus edulis) beds and Pacific oyster (Crassostrea gigas) coverage in the Dutch Wadden Sea. The oyster coverage is estimated in percentages by eye, and the survey took place during the intertidal mussel bed survey (spring)

There are, however, several reports of (mass) mortality of Pacific oysters (Cadée 2004; Soletchnik et al. 1999; Dankers et al. 2006; Wehrmann et al. 2006). Suffocation underneath large bundles of green algae (Ulva sp.) (Cadée 2004) or silt does occur. In France summer mortality occurs regularly (Soletchnik et al. 1999). In the summer of 2004 (August), several private persons reported mass mortality $(>50 \%)$ of oysters in the Dutch Wadden Sea. Especially near Ameland, but also near Texel, Terscheling and the dike of Lauwersoog high percentages of oysters died. There were also locations, however, where mass mortality did not occur (e.g., Balgzand and Eemshaven). In the summer of 2005 mass mortality occurred in several locations of the German Wadden Sea (Marc Herlyn, personnel communication).

Although mortality can reach up to $90 \%$ in some locations, so far the cause of mass mortality is not clear. There are no indications, however, that this mortality would bring the invasion of the Pacific oyster to a stop. The shells of oysters remain after mass mortality and form an excellent substrate for new settlement of Pacific oysters.

Possible effects of the increase of Pacific oysters in the Wadden Sea consist of a decrease in space for other organisms, a decrease in carrying capacity and habitat change.

Pacific oysters settle regularly in mussel beds (Mytilus edulis) and compete for space with this species (May 2006). Although Pacific oysters have taken over several mussel beds in the Dutch Wadden Sea, this is still considered only relevant at a small scale (Nehls et al. 2006). There are also several reports of mussel spat settling on Pacific oyster reefs. Thus, although Pacific oysters can overgrow mussel beds, they themselves again form substrates for mussels. This might in the end result in combined reefs.

In the German Wadden Sea almost all mussel beds are now considered oyster reefs (Nehls et al. 2006; Wehrmann et al. 2007). This may be due to the fact that in The Netherlands rejuvenation of mussel beds occurs, while in Germany most mussel beds are senescent.

As Pacific oysters are filter feeders, they may compete for food with other filter feeders, like mussels (Mytilus edulis) and cockles (Cerastoderma edule). In the Oosterschelde there seem to be indications that this is the case (Geurts van Kessel et al. 2003). In the 1990s the Pacific oyster biomass increased significantly in this area, while the mussel and cockle biomass decreased. However, effects of climate change on this change in bivalve species compensation cannot be ruled out. Nehls et al. (2006) consider competition for food and 
space with the Pacific oyster to be far less important for species displacement than climate change.

Pacific oysters create a hard three-dimensional substrate by forming reefs. Because of this, habitats change from soft to hard substrate. Fauna that prefer a soft substrate, such as cockles (Cerastoderma edule), might suffer from this habitat change. Fauna that prefer a hard substrate can benefit from the occurrence of Pacific oyster reefs. As a result, oyster reefs on tidal flats seem to harbour more species compared to the bare flats (van Broekhoven 2005; Markert 2006). Pacific oysters that attach to hard substrates like dikes and stones also induce an increase in species richness; however, when the covering percentage exceeds $50 \%$, the species richness declines again.

Although part of the effects of Pacific oyster growth might be seen as negative, it should be kept in mind that native oysters (Ostrea edulis) have always occurred in the Wadden Sea, and, although this concerns another species, the introduction of the Pacific oyster might in the end result in a (re-)establishment of reefs as habitat in the Wadden Sea.

As can be deduced from this overview of data on the development of the Pacific oyster in the Dutch Wadden Sea, there are limitations in the accuracy of quantitative data on actual biomass. As the Pacific oyster might cause ecological and economical problems in the Dutch Wadden Sea, it is important for Dutch policy making that quantitative monitoring of the biomass development and distribution of the Pacific oysters takes place.

Acknowledgments The majority of these investigations were financed by the ministry of LNV. We thank Achim Wehrmann and an anonymous reviewer whose comments on the first version greatly helped to transform a paper based on a PowerPoint presentation into something much more easy to read and comprehend.

Open Access This article is distributed under the terms of the Creative Commons Attribution Noncommercial License which permits any noncommercial use, distribution, and reproduction in any medium, provided the original author(s) and source are credited.

\section{References}

Baird D, Asmus H, Asmus R (2004) Energy flow of a boreal intertidal ecosystem, the Sylt-Rømø Bight. Mar Ecol Prog Ser 279:45-61

Brandt G, Wehrmann A, Wirtz KW (2008) Rapid invasion of Crassostrea gigas into the German Wadden Sea dominated by larval supply. J Sea Res 59:279-296

Brinkman AG, Bult T, Dankers N, Meijboom A, den Os D, van stralen MR, de Vlas J (2003) Mosselbanken: kenmerken, oppervlaktebepaling en beoordeling van stabiliteit. Rapport voor deelproject F1 van EVA II, tweede fase van het evaluatieonderzoek naar de effecten van schelpdiervisserij op natuurwaarden in de Waddenzee en Oosterschelde. Alterra rapport 707

Bruins RBW (1983) Crassostrea gigas op Texel. Correp Blad Ned Malacol Ver 215:1436-1438

Cadée GC (2000) Japanse oester (Crassostrea gigas) populaties tussen Oudeschild en Mok, Texel. Het Zeepaard 60:260-269

Cadée GC (2001) Herring gulls learn to fee don a recent invader in the Dutch Wadden Sea, the Pacific Oyster Crasostrea gogas. Basteria 65:33-42

Cadée GC (2004) Japanse oesters Crassostrea gigas gestikt onder algenbedekking in 2003. Het Zeepaard 64:110-114

Cadée GC (2008a) Oystercathers Haematopus ostralegus catching Pacific Oysters Crassostrea gigas. Basteria 72:25-31

Cadée GC (2008b) Hering gulls feeding again on Pacific Oysters Crassostrea gigas. In the Dutch Wadden Sea near Texel. Basteria 72:33-36

Cardoso JMF (2004) Intra- and interspecies comparison of the energy flow in various bivalve species in Dutch coastal waters by means of dynamic energy budgets. Ph.D. thesis, Rijksuniversiteit Groningen, Groningen 
Colautti RI, Ricciardi A, Grigorovich IA, Macisaac HJ (2004) Is invasion success explained by the enemy release hypothesis? Ecol Lett 7:721-733

Dankers N, Dijkman E, de Jong M, de Kort G, Meijboom A (2004) De verspreiding en uitbreiding van de Japanse Oester in de Nederlandse Waddenzee. Alterra rapport nr 909

Dankers N, Meijboom A, de Jong M, Dijkman E, Cremer J, Fey F, Smaal A, Craeymeersch J, Brummelhuis E, Steenbergen J, Baars D (2006) De ontwikkeling van de Japanse Oester in Nederland (Waddenzee en Oosterschelde) IMARES Rapport nr C040/06

de Kluijver M, Dubbeldam M (2003) De sublittorale hardsubstraat levensgemeenschap in de Oosterschelde. Ontwikkelingen in de periode 1985-2002. AquaSense rapport 1973-2

Diederich S (2005) Differential recruitment of introduced Pacific oysters and native mussels at the North Sea coast: coexistence possible? J Sea Res 53:269-281

Diederich S, Nehls G, van Beusekom J, Reise K (2005) Introduced Pacific Oysters (Crassostrea gigas) in the Northern Wadden Sea: invasion accelerated by warm summers? Helgol Mar Res 59:97-106

Drinkwaard AC (1999) Introductions and developments of oysters in the North Sea area: review. Helgol Meeresunters 52:301-308

Geurts van Kessel AJM, Kater BJ, Prins TC (2003) Veranderende draagkracht van de Oosterschelde voor kokkels. Rapport RIKZ/2003.043

Goudswaard PC, Kesteloo JJ, van Stralen MR (2007) Het bestand aan Japanse Oesters in het litoraal van het Nederlands deel van de Waddenzee in 2004-2006. IMARES Rapport C012/07

Hagmeier A (1941) Die intensive Nutzung des nordfriesischen Wattenmeeres durch Austern- und Muschelkultur. Z Fischerei 39:105-165

Hagmeier A, Kändler R (1927) Neue Untersuchungen im nordfriesischen Wattenmeer und auf den fiskalischen Austernbänken. Wiss Meeresunters (Abt. Helgoland) 16:90

Markert A (2006) Untersuchungen der Lebensgemeinschaft eines durch die Pazifische Auster (Crassostrea gigas) neu entstandenen Austernriffs im Ostfriesischen Wattenmeer. Diploma thesis FU Berlin

May P (2006) Nahrungskonkurrenz zwischen Crassostrea gigas (ThunBERG, 1793) und Mytilus edulis LinNAEus 1758. Diploma thesis Universität Oldenburg

Nehls G, Diederich S, Thieltges DW, Strasser M (2006) Wadden Sea mussel beds invaded by oysters and slipper limpets: competition or climate control? Helgol Mar Res 60:135-143

Nehring S (2003) Pacific oysters in the European Wadden Sea: an irreversible impact in a highly protected ecosystem. Special issue on invasive alien species and protected areas. Aliens 17:20-21

Reise K (1982) Long-term changes in the macrobenthic invertebrate fauna of the Wadden Sea: are the polychaetes about to take over? Neth J Sea Res 16:29-36

Reise K (1998) Pacific oysters invade mussel beds in the European Wadden Sea. Senckenb Marit 28:167-175

Schmidt A, Wehrmann A, Dittmann S (2008) Population dynamics of the invasive Pacific oyster Crassostrea gigas during the early stages of an outbreak in the Wadden Sea (Germany). Helgol Mar Res 62:367-376. doi:10.1007/s10152-008-0125-8

Soletchnik P, Le Moine O, Faury N, Razet D, Geairon P, Goulletquer P (1999) Mortalité de l'huître Crassostrea gigas dans le bassin de Marennes-Oléron: étude de la variabilité spatiale de son environnement et de sa biologie par un système d'informations géographiques (SIG). Aquat Living Resour 12(2):131-143

Tydeman P (2008) Japanse oesters naar de (Wadden)zee gedragen? Het Zeepaard 68:109-114

van Broekhoven W (2005) Faunal diversity on beds of the Pacific oyster (Crassostrea gigas) in the Oosterschelde estuary. Nederlands Instituut voor Visserij-Centrum voor Schelpdier Onderzoek, Intern RIVO rapport

Wehrmann A, Herlyn M, Bungenstock F, Hertweck G, Millat G (2000) The distribution gap is closed-first record of naturally settled Pacific oysters Crassostrea gigas in the East Frisian Wadden Sea. Senckenb Marit 30:153-160

Wehrmann A, Markert A, May P, Schieck P, Schmidt A (2006) Gefährdungs-potential der eulitoralen Miesmuschelbänke im Niedersächsischen Wattenmeer durch die Bioinvasion der Pazifischen Auster Crassostrea gigas. Report Nieders. Wattenmeer-Stiftung

Wehrmann A, Markert A, Schmidt A (2007) Miesmuschelbank: ein verlorener Lebensraum? Die Einwanderung der Pazifischen Auster in das Wattenmeer und ihre Folgen. Natur- und Umweltschutz 6(1):10-14 